\title{
AZ ÉPÍTETT KÖRNYEZET HATÁSA A LEVEGŐMINŐSÉGRE - LEVEGŐMINŐSÉG MÉRÉSEK BUDAPESTEN HORDOZHATÓ MÜSZEREKKEL
}

\author{
Csapó Péter ${ }^{(1,2)}$ (D), Mészáros Róbert ${ }^{(2)}$ \\ ${ }^{(1)}$ Pest Megyei Kormányhivatal Környezetvédelmi és Természetvédelmi Főosztály \\ 1016 Budapest, Mészáros u. 58/A. \\ ${ }^{(2)}$ Eötvös Loránd Tudományegyetem, Meteorológiai Tanszék, \\ 1117 Budapest, Pázmány Péter sétány 1/A. \\ e-mail: pcsapo91@gmail.com,mrobi@nimbus.elte.hu
}

\section{Bevezetés}

Az épített környezet nagy hatással bír a városi légszennyezettség térbeli mintázataira. Akár kis távolságon belül is nagy koncentráció eltérések adódhatnak, amit a helyhez kötött légszennyezettségi mérőállomások adatai esetenként nem írnak le. Ezzel szemben hordozható légszennyezettség-mérö müszerekkel történő vizsgálatok során lehetőség nyílik a helyhez kötött, automata mérőhálózat által mért adatoknál - ugyan valamivel kevésbé pontos, de mind térben, mind pedig időben jobb felbontású adatok mérésére, ezáltal az eltérő topológiával rendelkező útvonalak légszennyezettségi viszonyainak finomabb feltérképezésére. A városon belüli légszennyezettségi viszonyok térbeli eloszlását levegőkémiai modellekkel is leírhatjuk (1. pl. Leelőssy et al., 2017; Kovács et al., 2019), de a beépítettségi viszonyok tényleges hatásait, és az egyes útvonalak menti légszennyezettséget elsősorban a mobil mérések képesek visszaadni.

A nagyvárosokban történő kerékpáros közlekedés során a kerékpárosok sokszor közvetlenül a gépjármü forgalom mellett kénytelenek haladni, amelynek következtében figyelembe véve a fizikai aktivitás következtében fellépő megnövekedett légzésszámot fokozottan ki vannak téve a légszennyezettség veszélyeinek. A városi kerékpározás emiatt rövid és hosszú távon egyaránt negatív egészségügyi kockázatokat hordoz magában. A fenti kockázatok csökkentése céljából szükséges olyan útvonalak meghatározása, amelyek mind a forgalom, mind pedig a beépítettség vonatkozásában alkalmasak a kerékpáros közlekedésre.

Budapesten végzett méréseink során vizsgáltuk többek között a városi zöldterületek, illetve a dunai ventillációs csatorna levegőminőségre gyakorolt hatását, továbbá a szük, magas épületekkel körülvett, kanyon-szerü utak, valamint a forgalmas kereszteződésekben kialakuló hot-spot területek szennyezettségét. A mérési eredményeink térképi ábrázolását követően lehetőség nyílik azoknak az útvonalaknak a meghatározására, ahol a forgalom nagysága, illetve a beépítettség olyan mértékü negatív hatást gyakorol a levegő minőségére, amelynek következtében a kerékpáros közlekedés az érintett útvonalon elkerülendő.

\section{Légszennyezettség vizsgálata kerékpárutak mentén}

A városokban, szabadtéri környezetben ingázással eltöltött idő nem számottevő a zárt térben töltött időhöz képest, ennek ellenére az ez idő alatt belélegzett szennyezőanyag mennyisége aránytalanul magas a napi kitettséghez viszonyítva (Fruin et al., 2008). Különösen veszélyes ebből a szempontból az aktív közlekedési módok választása. A kerékpárral közlekedők a kerékpárutak kialakítása miatt sokszor fokozott szennyezettségnek vannak kitéve. A fokozott kitettséget pedig súlyosbítja a tény, hogy a megnövekedett fizikai aktivitás következtében a légzésszám is megnövekszik, a percventilláció (a belélegzett levegő térfogata 1 perc alatt) értéke akár 2-4,5-szöröse lehet az egyéb közlekedési módot választókhoz képest (Zuurbier et al., 2009; Int Panis et al., 2010). Ezzel párhuzamosan a tüdőben lerakódó légszennyező 
anyagok mennyisége is emelkedik. A közlekedési eredetü légszennyezők pedig már a rövid távú kitettség esetén is negatív hatással lehetnek többek közt a szív- és érrendszerre, például a szívfrekvencia-variabilitásra, a vérnyomásra, a légzésre, illetve a tüdő müködésére is (Weichental et al., 2011; Li et al., 2017). A kerékpárutakon mérhető szennyezettséget számos aspektusból vizsgálták már. Az egyes közlekedési módok használata során történő kitettség vizsgálatok eredménye alapján a kerékpárosok aeroszol részecske (PM), ultra-finom részecskék (UFP), illékony szerves vegyületek (VOC) és szén-monoxid (CO) kitettsége alacsonyabb, mint a jármüvekben utazóké, ugyanakkor a hosszabb menetidő, és a növekvő légzésszám ezt nagyjából kiegyenlíti, illetve akár meg is fordíthatja. (O’Donogue et al., 2007; Teschke et al., 2012).

A szennyezettség időbeli mintázatainak vizsgálatakor megállapították, hogy a csúcsidőt elkerülve a szennyezőanyag-expozíció jelentősen, bizonyos szennyezőanyagok esetén akár 20-30\%-kal is csökkenthető (Kaur et al., 2005; Hertel et al., 2008). Figyelembe véve, hogy sokan közlekedési eszközként használják a kerékpárt, a munkába- és onnan hazatekerés ideje egybeesik a csúcsforgalom idejével. Minderre tekintettel kiemelt figyelmet kell fordítani a szennyezettség térbeli mintázatainak vizsgálatára, amellyel alternatív útvonalakat meghatározva a csúcsidőben történő kitettség csökkentésére is lehetőség nyílik.

Dons et al. (2012) koromra vonatkozó vizsgálata alapján a megfelelő útvonal kiválasztásával a kitettség kevesebb, mint a felére csökkenthető. Pattinson (2009) kutatása során a kerülő úton mért átlagos CO expozíció 42\%-kal volt alacsonyabb. míg ugyanez az érték a $\mathrm{PM}_{1,0}$-nál $31 \%$, míg az UFP-nél 53\% volt. A beépítettség hatását állapította meg Berghmans et al. (2009), aki a magas házakkal körülvett forgalmas útszakaszokon mérte a legmagasabb koncentráció értékeket. Peters et al. (2014) eredményei a városi zöldterületek pozitív hatására, illetve a forgalmas kereszteződésekben mérhető koncentráció-csúcsokra hívták fel figyelmet.

\section{A PM2,5 térbeli mintázatának vizsgálata Budapesten}

Méréseinket két DustTrak 8532 típusú hordozható légszennyezettség mérő eszközzel végeztük. A DustTrak 8532 egy olyan lézer fotométer, amely a beszívott részecskékről szórt fényt feszültséggé alakítja, majd a feszültség nagyságából határozza meg a tömegkoncentrációt. Tekintettel arra, hogy az aeroszolok kémiai és fizikai tulajdonságai minden városban eltérőek lehetnek, ez pedig befolyásolhatja a müszer által rögzített értékeket, a DustTrak müszerek pontosságát összehasonlítottuk az Eötvös Loránd Tudományegyetem BpART mérőállomásán ( $\varphi$ : 47²8'25,22” É.sz.; $\quad \lambda$ : 1903’48,65” K.h, h: $117 \mathrm{~m}$ tszf.) (http://salma.web.elte.hu/BpArt/index.html) lévő, kétkörös kifagyasztó rendszerrel összekapcsolt kúpos elemü oszcilláló mikromérleg (TEOM-FDMS) által mért tömegkoncentráció értékekkel (Csapó et al., 2018). A vizsgálatok során kapott eltérést korrekciós faktorként vettük figyelembe a méréseink során. Méréseinket Budapesten, különböző útvonalakon végeztük, az adott szakaszokat többször, eltérő időjárási helyzetben, különböző napszakokban is bejárva. Az adatgyüjtést sürű mintavételezéssel (az egyik, rövidebb útvonalon 5 másodpercenként, a másikon fél percenként) végeztük és a vizsgált útvonalak egyes pontjaira az útvonalon mért értékek átlagától való eltéréseket határoztuk meg. 


\section{A zöldterület, a gépjármü-forgalom, valamint a beépítettség hatása a $\mathbf{P M} \mathbf{M}_{2,5}$ koncentrációra}

\section{1. mérési kampány}

Az egyik mérési sorozat a főváros VII. és XIV. kerületének határán történt a Thököly úton, egy hozzávetölegesen $1 \mathrm{~km}$ hosszúságú útvonalon. A $\mathrm{PM}_{2,5}$ koncentrációadatokat $5 \mathrm{mp}$-es felbontásban mértük a DustTrak 8532 szenzorral, míg a térképi ábrázolás céljából a GPS koordinátákat a GPS Logger nevü telefonos alkalmazással rögzítettük. Ez másodperces felbontásban adja meg a földrajzi koordinátákat, így az adatsorból kiszürtük azokat a koordinátapontokat, amelyek időbélyegzője megegyezett a légszennyezettség mérő müszer által rögzített adatok idejével.

A vizsgált útvonal két különböző beépítettségü szakaszra osztható, amelyeknek határa a kerülethatárt is jelentő Dózsa György út. A XIV. kerületi részen az épületek sokkal lazábban helyezkednek el, emellett tágasabb terek is biztosítják a levegő szabadabb áramlását. Ezzel szemben a VII. kerületi rész nagyfokú beépítettséggel jellemezhető, közvetlenül az útszakasz mentén, több emelet magas épületek húzódnak, amelyek gátolják az átszellőzést, és a gépjármüvekből származó légszennyező anyagok távozását, kanyon-hatást eredményezve (1. ábra).

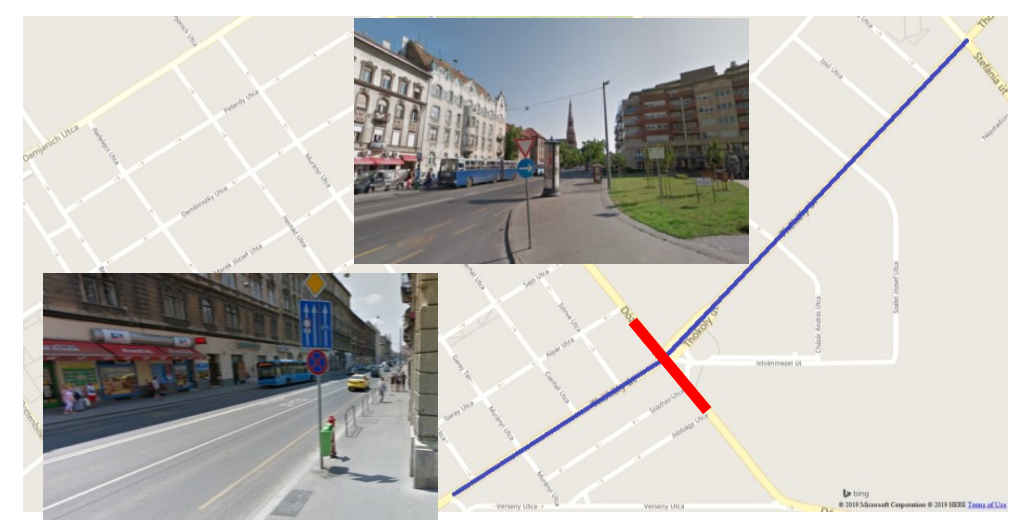

1. ábra: A vizsgált útvonal (piros vonallal jelölve a szakaszhatár).

A két útszakaszon a forgalom nagysága nem tér el egymástól, továbbá a kerékpársávot mindkét szakaszon közvetlenül a forgalmi sávok mentén alakították ki, így az egyes szakaszokon mérhető szennyezettség-különbségeket javarészt az eltérö beépítettségi karakterisztika okozza.

A méréseket összesen 100 alkalommal végeztük el 2019.02.06. és 2019.03.04. között, ügyelvén arra, hogy a koncentráció térbeli eloszlását eltérő napokon (hétvége-hétköznap), napszakokban (csúcsforgalom), illetve időjárási viszonyok között is vizsgáljuk.

$\mathrm{Az}$ egyes megtett körök során meghatároztuk a mérések átlagát, majd az egyes mérési pontok átlagtól való eltérését. Ezt követően az útvonalat a GPS koordináták $0,0001^{\circ}$-ra történő kerekítésével $\sim 10 \mathrm{~m} \times 10 \mathrm{~m}$-es területekre osztottuk, és átlagoltuk az egyes területekre eső átlagtól való eltéréseket.

A kapott eredmények alapján megállapítható, hogy a beépítettség kiemelt szereppel bír a kerékpárutakon mérhető légszennyezettség tekintetében (2. ábra). A laza beépítettséggel jellemezhető XIV. kerületi szakaszon a legtöbbször az átlagosnál jelentősen alacsonyabb koncentráció értékeket sikerült kimutatni, ezzel szemben a kanyon-szerü kialakítással rendelkező VII. kerületi útszakaszon az átlagos értékeket számottevően meghaladó $\mathrm{PM}_{2,5}$ koncentráció volt jellemző A XIV. kerületi szakasz végén, a Stefánia útnál, szintén gyakori volt az átlagot jelentősen meghaladó koncentráció, amelynek oka a forgalmi jelzőlámpában 
keresendőek. A lámpa miatti fékezés, illetve gázadás hatására a koncentráció megemelkedett, ugyanakkor ez a jelenség erősen forgalomfüggő.

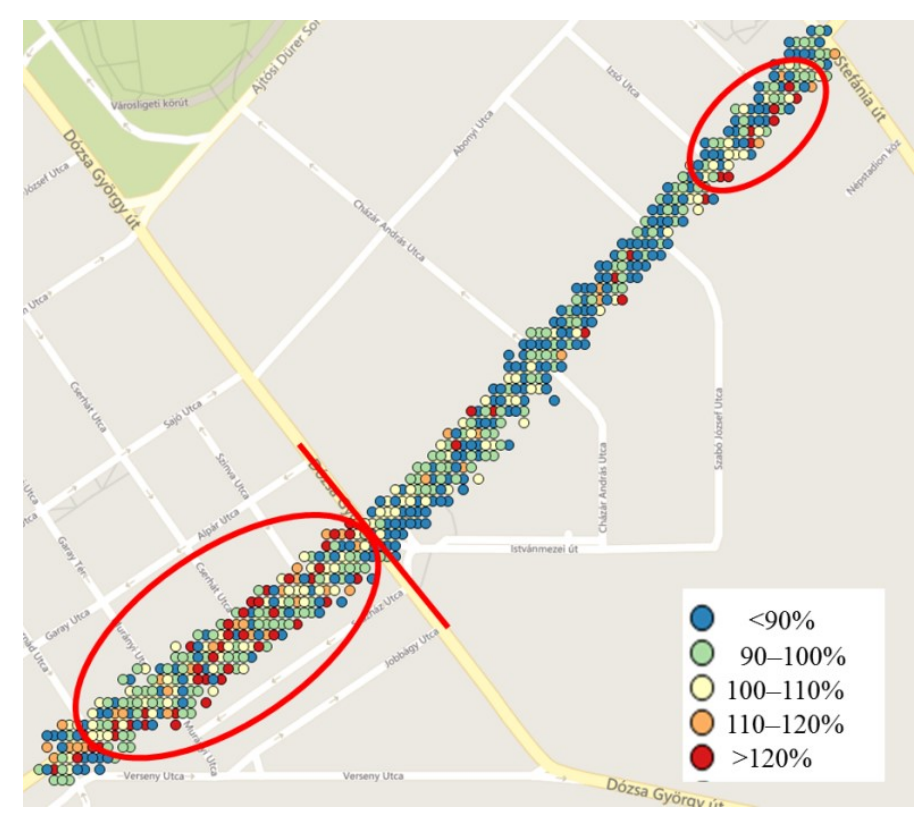

2. ábra: $\mathrm{A} \mathrm{PM}_{2,5}$ koncentráció értékek átlagtól való eltérése a vizsgált útvonal egyes pontjain (Megj.: a pontos szórása a GPS pontatlanságából adódik).

\section{2. mérési kampány}

Egy másik mérési sorozat során egy előre meghatározott, $5 \mathrm{~km}$ hosszúságú útvonalon végeztünk méréseket, amely útvonal számos eltérő beépítettséggel rendelkező szakaszt foglal magába. A választott útvonal érintette a Duna-part jó átszellőzéssel, és közepes forgalommal rendelkező budai oldalát, a kanyon-szerü kialakítással jellemezhető szük belvárosi utcákat. A városi zöld területet az Erzsébet-tér reprezentálta, míg a magas épületekkel körülvett, nagy forgalmú utak okozta szennyezőanyag-koncentrációt az Erzsébet-tér és a Kálvin-tér közötti útszakaszon vizsgáltuk (3. ábra). Korábban, az azonos szakaszon már végeztünk méréseket, ezek eredményeit Csapó et al. (2018) munkában mutattuk be, ahol a mérési eljárást is részleteztük. Jelen tanulmányban egy újabb mérési időszak adatsorát elemezzük.

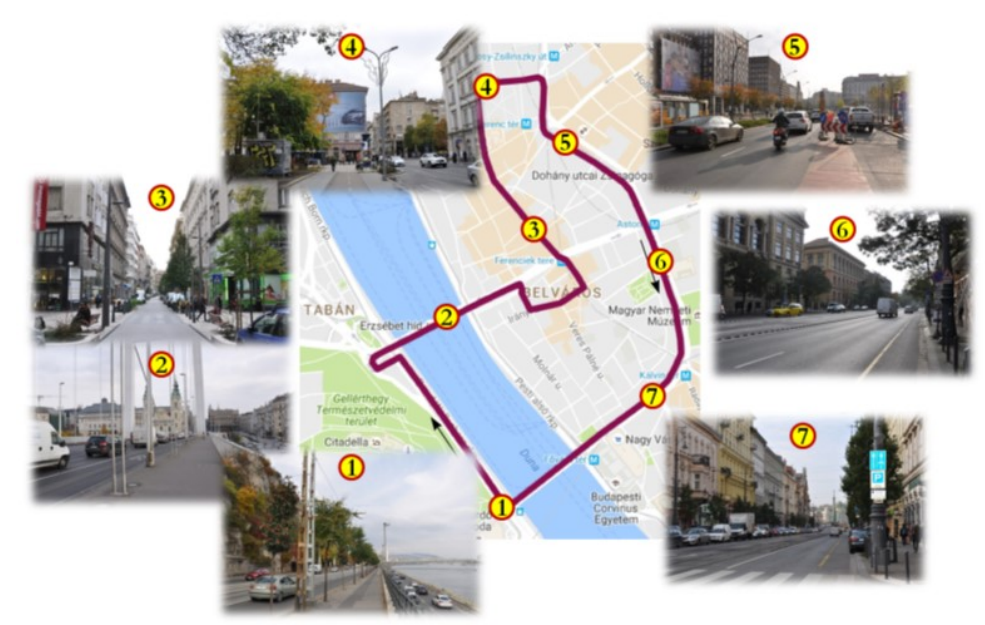

3. ábra: A vizsgált útvonal (Csapó et al., 2018 alapján). 
A mérések során a mintavétel gyakorisága 30 másodperc volt. A térképi ábrázolás érdekében a GPS koordinátákat egy L80-M39 Qectel GPS modul segítségével szintén rögzítettük. Az adatok feldolgozása az alábbiak szerint történt: minden megtett kör során megnéztük a kör átlagát, majd az egyes mérési pontok átlagtól való eltérését. A térképi feldolgozás során a bejárt útvonalat $100 \mathrm{~m} \times 100 \mathrm{~m}$-es rácsnégyzetekre osztottuk, majd az egyes négyzetekbe eső átlagtól való eltéréseket átlagoltuk. 2016 és 2018 között összesen 50 kört tettünk meg az útvonalon, különböző napszakban és eltérő időjárási helyzetben. Az 50 mérési kör összesített eredményét a 4. ábra mutatja.

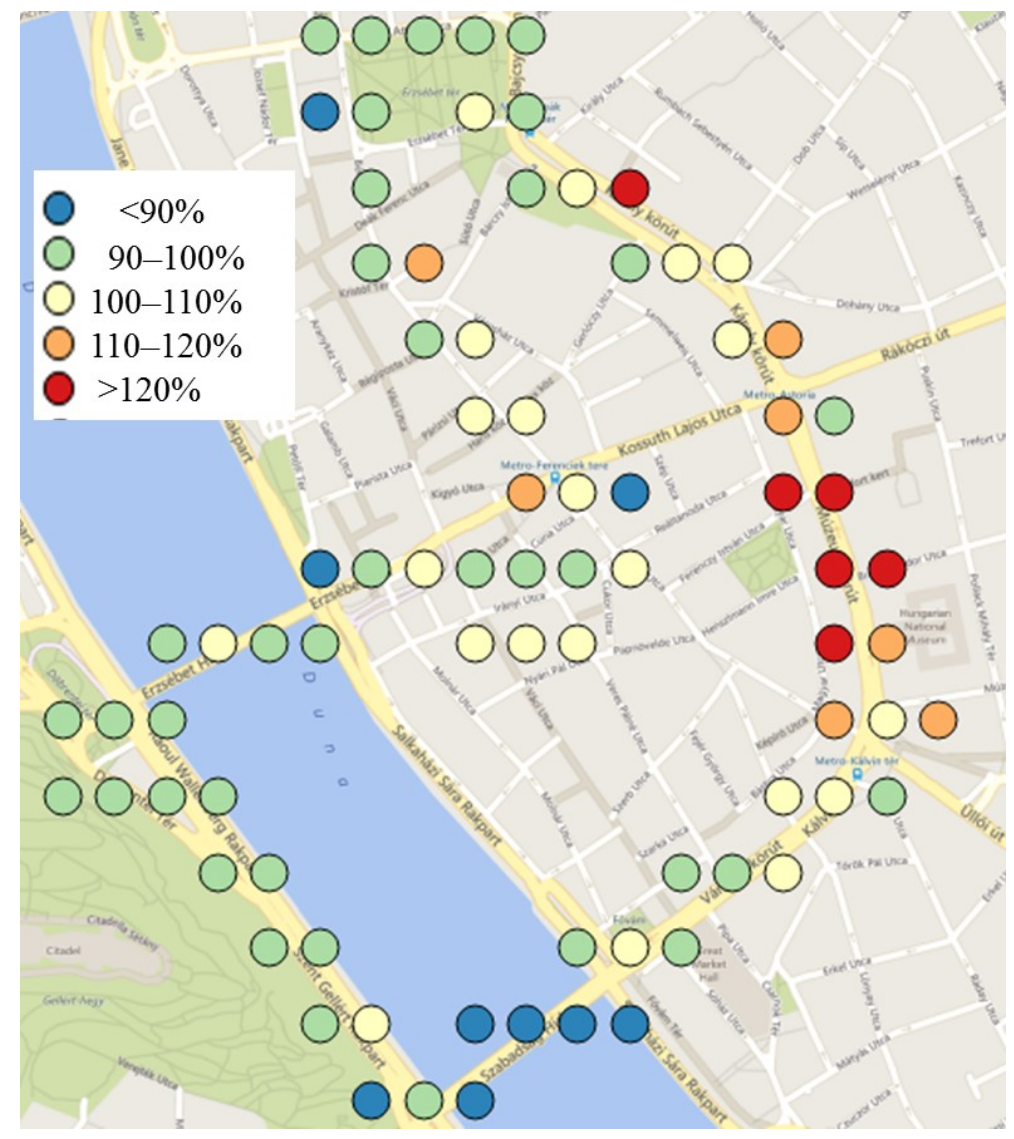

4. ábra: A $\mathrm{PM}_{2,5}$-koncentráció átlaghoz viszonyított értékei \%-ban kifejezve.

Az eredmények alapján megállapítható, hogy a magas épületekkel körülvett szük utcákban még alacsony gépjármü forgalom esetén is az átlagnál magasabb szennyezettség tapasztalható. Abban az esetben, ha a magas épületekkel körülvett utak intenzív gépjármü forgalommal párosulnak, úgy a szennyezőanyag koncentráció akár az átlagérték másfélszeresét is elérhette. A városi zöldterületet reprezentáló Erzsébet-téren a várakozásoknak megfelelően az átlagnál alacsonyabb szennyezettségi értéket mértünk, míg a két vizsgált hídon tapasztalható koncentráció-különbséget kizárólag az eltérő nagyságú gépjármüforgalom eredményezte.

Eredményeinkből kiderül, hogy a forgalom nagysága mellett a beépítettség típusa, valamint mértéke is nagy szerepet játszik a $\mathrm{PM}_{2,5}$ térbeli mintázatának kialakulásában. A budapesti kerékpárutak kialakítása során a szennyezőanyag-expozíció, és ezáltal a káros egészségügyi hatások csökkentése érdekében kiemelt figyelmet kell fordítani erre a kérdéskörre is. 


\section{Összefoglalás}

Az eredményekből látszik, hogy a szennyezettség térbeli mintázatának vizsgálata nem elhanyagolható, ha csökkenteni szeretnénk a kerékpárosok expozícióját, és ezáltal a káros egészségügyi hatásokat. Budapesten a levegő minőségét 12 fix telepítésü mérőállomáson vizsgálják. Az ezeken a mérőállomásokon mért értékek nagy pontosságúak, ugyanakkor hátrányuk a szük területi lefedettség. A hordozható légszennyezettség-mérő müszerek ezzel szemben kisebb pontosságuk ellenére, sokkal jobb tér-, és időbeli felbontásban határozható meg a légszennyezettség. Megfelelő számú mérés esetén a mérésekből nyert adatok alkalmasak a szennyezőanyagok mintázatainak elemzésére összetett, beépített környezetben.

Köszönetnyilvánítás: A kutatásokat a Nemzeti Kutatási, Fejlesztési és Innovációs Alap K116506, K-128805 és K-128818 pályázatai támogatták.

\section{Hivatkozások}

Berghmans, P., Bleux, N., Int Panis, L., Mishra, V.K., Torfs, R., van Poppel, M., 2009: Exposure assessment of a cyclist to PM10 and ultrafine particles. Science of The Total Environment, 407(4): 1286-1298. https://doi.org/10.1016/j.scitotenv.2008.10.041

Csapó, P., Mészáros R., Leelőssy Á., 2018: PM2.5 koncentráció mérések mobil mérőmüszerekkel budapesti belvárosi kerékpár útvonalon. in: Pongrácz, R., Mészáros R., Kis A. (szerk.) Aktuális környezeti problémák az időjárás és az éghajlat összefüggésében. Egyetemi Meteorológiai Füzetek, 30: 35-42. https://doi.org/10.31852/EMF.30.2018.035.042

Dons, E., Int Panis, L., van Poppel, M., Theunis, J., Wets, G., 2012: Personal exposure to black carbon in transport microenvironments. Atmospheric Environment, 55: 392-398. https://doi.org/10.1016/j.atmosenv.2012.03.020

Fruin, S.A., Westerdahl, D., Sax, T., Sioutas, C., Fine, P.M., 2008: Measurements and predictors of on-road ultrafine particle concentrations and associated pollutants in Los Angeles. Atmospheric Environment, 42: 207-219. https://doi.org/10.1016/j.atmosenv.2007.09.057

Hertel, O., Hvidberg, M., Ketzel, M., Storm, L., Stausgaard, L., 2008: A proper choice of route significantly reduces air pollution exposure - A study on bicycle and bus trips in urban streets. Science Of The Total Environment, 389(1): 58-70. https://doi.org/10.1016/j.scitotenv.2007.08.058

Int Panis, L., de Geus, B., Vandenbulce, G., Villems, H., Deagraeuwe, B., Bleux, N., Mishra, V., Thomas, I., Meeusen, R., 2010: Exposure to Particulate Matter in Traffic: A

Comparison of Cyclists and Car Passengers. Atmospheric Environment, 44: 2263-2270. https://doi.org/10.1016/j.atmosenv.2010.04.028

Kaur, S, Nieuwenhuijsen, M., Colvile, R., 2005: Personal exposure of street canyon intersection users to PM2.5, ultrafine particle counts and carbon monoxide in Central London, UK. Atmospheric Environment, 39: 3629-3641. https://doi.org/10.1016/j.atmosenv.2005.02.046

Kovács, A., Leelössy, Á., Mészáros, R., Lagzi, I., 2019: Online coupled modelling of weather and air quality of Budapest using the WRF-Chem model. Idöjárás, 123(2): 203-215. https://doi.org/10.28974/idojaras.2019.2.5

Leelössy, Á., Lagzi, I., Mészáros, R., 2017: Spatial and temporal pattern of pollutants dispersed in the atmosphere from the Budapest Chemical Works industrial site. Időjárás, 121(2): 101-115. 
Li, Z., Che, W., Frey, H.C., Lau, A.K.H., Lin, C., 2017: Characterization of $\mathrm{PM}_{2.5}$ exposure concentration in transport microenvironments using portable monitors. Environmental Pollution, 228: 433-442. https://doi.org/10.1016/j.envpol.2017.05.039

O'Donoghue, R.T., Gill, L.W., McKevitt, R.J., Broderick, B., 2007: Exposure to hydrocarbon concentrations while commuting or exercising in Dublin. Environment International, 33 (1): 1-8. https://doi.org/10.1016/j.envint.2006.05.005

Pattinson, W.J., 2009: Cyclist exposure to traffic pollution: microscale variance, the impact of route choice and comparisons to other modal choices in two new zealand cities. University of Cumterbury, 164p.

Peters, J., van den Bossche, J., Reggente, M., van Poppel, M., de Baets, B., Theunis, J., 2014: Cyclist exposure to UFP and BC on urban routes in Antwerp, Belgium. Atmospheric Environment, 92: 31-43. https://doi.org/10.1016/j.atmosenv.2014.03.03

Teschke, K., Reynolds, C.C.O., Ries, F.J., Gouge, B, Winters, M., 2012: Bicycling: Health Risk or Benefit? University Of British Columbia Medical Journal, 3(2): 4-11.

Zuurbier, M., Hoek, G., Van den Hazel, P., Brunekreef B., 2009: Minute ventilation of cyclists, car and bus passengers: an experimental study. Environmental Health, 8: 48 https://doi.org/10.1186/1476-069X-8-48

Weichenthal, S., Kulka, R., Dubeau, A., Martin, C., Wang, D., Dales, R., 2011: Traffic related air pollution and acute changes in heart rate variability and respiratory function in urban cyclists. Environmental Health Perspectives, 119: 1373-1378.

https://doi.org/10.1289/ehp.1003321

\section{Internetes hivatkozások}

http://salma.web.elte.hu/BpArt/index.html

\section{ORCID:}

Csapó P. (D) https://orcid.org/0000-0003-3252-1217

Mészáros R. (D) https://orcid.org/0000-0002-0550-9266 